\title{
PHENOLOGY AND YIELD OF THE 'ROXO DE VALINHOS’ FIG CULTIVAR IN WESTERN POTIGUAR ${ }^{1}$
}

\author{
FRANCISCO SIDENE OLIVEIRA SILVA ${ }^{2 *}$, EDUARDO CASTRO PEREIRA ${ }^{2}$, VANDER MENDONÇA $^{2}$, ROSEANO \\ MEDEIROS DA SILVA ${ }^{2}$, ANDERSON ARAUJO ALVES ${ }^{2}$
}

\begin{abstract}
The 'Roxo de Valinhos' fig is one of the most widely grown varieties in the world, however, there are still few studies on the phenology and yield of fig trees, especially in semi-arid regions. This study evaluated the phenology and yield aspects of the 'Roxo de Valinhos' fig cultivar in Western Potiguar. The experiment was carried out from July to December 2015 in the didactic orchard of the Federal Rural University of the Semi-Arid, UFERSA. The following phenological aspects were analyzed: pruning at the beginning of budding, emergence and maturity of the first fruit, beginning of harvest, length and diameter of branches, number of fruits per branch, length and diameter of fruits, absolute growth rate, yield per plant, number of fruits per plant, and fruit weight. We used descriptive statistics; for quantitative and qualitative characteristics, we used regression analysis and means test, through Tukey's test at 5\% probability. Fig trees showed good adaptability to semi-arid regions and precocity when compared to fig trees from temperate regions, in all phenological stages; the studied cultivar showed promising results for cultivation in this region.
\end{abstract}

Keywords: Ficus carica L.. Growth rate. Fruit development.

\section{FENOLOGIA E PRODUÇÃO DA FIGUEIRA CV. ROXO DE VALINHOS NO OESTE POTIGUAR}

RESUMO - A figueira 'Roxo de Valinhos' é uma das variedades mais cultivadas no mundo, no entanto, ainda existem poucos estudos sobre a fenologia e produção de figueiras, especialmente em regiões semi-áridas. Este estudo avaliou os aspectos fenológicos e produtivos da cultivar de figueira 'Roxo de Valinhos' no Oeste Potiguar. O experimento foi realizado de julho a dezembro de 2015 no pomar didático da Universidade Federal Rural do Semi-Árido, UFERSA. Os seguintes aspectos fenológicos foram analisados: poda do início ao brotamento, emergência e maturação do primeiro fruto, início da colheita, comprimento e diâmetro dos ramos, número de frutos por ramo, comprimento e diâmetro dos frutos, taxa de crescimento absoluto, rendimento por planta, número de frutos por planta e peso do fruto. Utilizamos estatística descritiva; Para as características quantitativas e qualitativas, utilizou-se análise de regressão e teste de médias, através do teste de Tukey a 5\% de probabilidade. As figueiras mostraram boa adaptabilidade às regiões semi-áridas e precocidade quando comparadas às figueiras das regiões temperadas, em todos os estádios fenológicos; A cultivar estudada apresentou resultados promissores para o cultivo nesta região.

Palavras-chave: Ficus carica L.. Taxa de crescimento. Desenvolvimento de frutos.

\footnotetext{
*Corresponding author

${ }^{1}$ Received for publication in $04 / 27 / 2016$; accepted in $10 / 17 / 2016$.

Paper extracted from the master's dissertation of the first author, funded by CAPES.

${ }^{2}$ Department of Crop Science, Universidade Federal Rural do Semi-Árido, Mossoró, RN, Brazil; f_sidene@hotmail.com, edu_castro7@hotmail.com, vanderm2000@hotmail.com, medeiros_ufersa@hotmail.com, alves.araujo07@gmail.com.
} 


\section{INTRODUCTION}

The fig tree (Ficus carica L.) is one of the oldest known fruit trees and among the most cultivated species in the countries of the Mediterranean coast, especially in Turkey, Algeria, Greece, Italy and Spain (SOUZA et al., 2014). Originating in the Middle East, it is well adapted to humid and temperate subtropical climates, which allows its cultivation in various regions, such as the southeast of Brazil (FRONZA et al., 2010).

In Brazil, the fig production area covers $2,807 \mathrm{ha}$, with an average yield of $9,991 \mathrm{~kg} \mathrm{ha}^{-1}$. Of the fig-producing states in Brazil, Rio Grande do Sul has a harvest area of 1,573 ha, followed by São Paulo (546 ha) and Minas Gerais (497 ha) (IBGE, 2016). According to the Brazilian Institute of Geography and Statistics (2014), fig production increased by $18.1 \%$ from 2004 to 2013 .

In addition to the traditional fruit trees, new species are important as a means of production diversification for temperate crops, and using fig, for its adaptation skills, may be one such alternative according to previous studies in the Brazilian northeast (CELEDONIO et al., 2013).

Chagas et al. (2012) report that there is not yet a large number of rustic cultivars with good adaptation to tropical regions; thus, studies on the phenology (growth and development) of temperate crops and their adaptations to conditions of warmer regions are of paramount importance.

Camilo et al. (2013) propose that the knowledge of their biology and, in particular, their phenology, is one of the initial steps in the knowledge of plants.

For Serrano et al. (2008), the duration of each developmental stage of development differs according to various factors such as genotype, edaphoclimatic conditions, and crop management; in this way, knowledge about phenology is essential for the adoption of adequate agricultural practices and for the development of strategies.

Knowledge of the different stages of development, as well as their duration, allows adjustments to favorable and unfavorable periods of the vegetative and reproductive cycles of the plant (SILVA et al., 2012).

Araújo, Santos and Lemos (2014) admit that the knowledge of phenology allows assessing the availability of fruits throughout the year, at different times, and under edaphoclimatic conditions.

Notwithstanding, Ferraz et al. (1999) report that the phenology of plant species has been relatively little studied in tropical regions, observing a lack of terms and standardized methods.

'Roxo de Valinhos' is among the most produced and marketed fig varieties in Brazil, since it has great economic value, hardiness, high vigor and yield, besides a good adaptation to drastic pruning (SOUZA et al., 2014).

The fig tree has a great potential for cultivation in the region of Ceará, based on high yield potential in the climatic conditions of Chapada do Apodi (FREITAS et al., 2015).

This study aimed to evaluate the phenology and yield of the 'Roxo de Valinhos' fig cultivar in Western Potiguar, Brazil.

\section{MATERIAL AND METHODS}

The research was conducted from July to December 2015 in the didactic orchard of the Federal Rural University of the Semi-Arid (UFERSA), located in the municipality of Mossoró-RN, at $5^{\circ}$ $11^{\prime} 15^{\prime}$ ' south latitude and $37^{\circ}$ 20'39', west longitude, at an altitude of 18 meters. The climate of the region, according to the Köppen classification, is typed BSwh, hot and dry, with an average annual rainfall of $673.9 \mathrm{~mm}$ and average temperature and relative air humidity of $27^{\circ} \mathrm{C}$ and $68.9 \%$, respectively. The rainy season occurs from February to June, with very low possibility of rain between August and December (CARMO FILHO; OLIVEIRA, 1995). Figure 1 shows the climatic data of the trial period (year 2015).

The spacing of fig plants was $2 \times 1.5 \mathrm{~m}$. The plants were 2 years old and in their first year of production. Pruning and conduction of plants were performed on 24 July 2015. Plants were pruned to $50 \mathrm{~cm}$ from the ground and cultivated with three limbs throughout the growing season, leaving branches with a length of $40 \mathrm{~cm}$ for the formation of new branches. For irrigation, we used a micro-sprinkling irrigation system with one sprinkler per plant, providing a daily average of $30 \mathrm{~L}$ of water per plant. Weed control was carried out mechanically through mowing.

For the phenological analyses of the vegetative growth of fig plants, 15 plants of the cv. 'Roxo de Valinhos' were used. Evaluations began 30 days after pruning, when all plants were already fully sprouted. We marked two branches per limb, totaling six branches per plant; evaluations were performed every seven days, thus differentiating from the evaluations carried out in colder regions, which are usually done in 30-day intervals due to slow vegetative growth. 


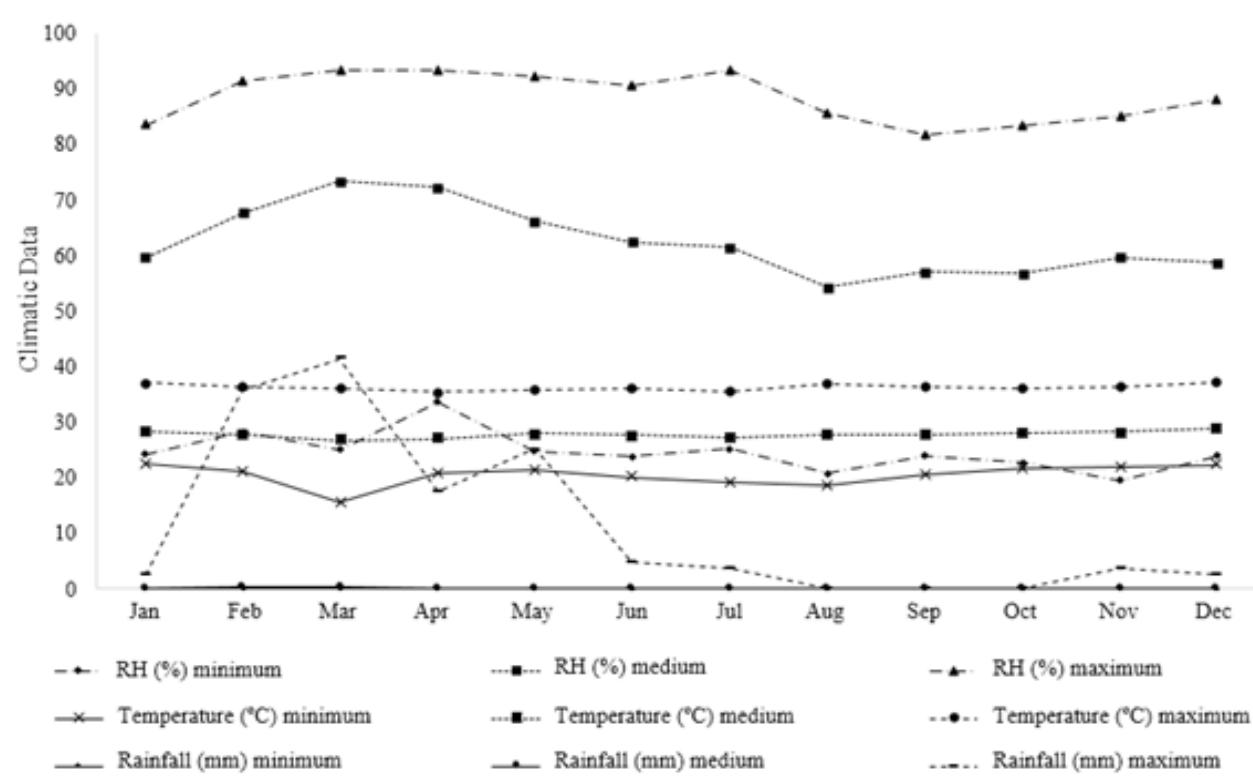

Figure 1. Climatic data of Relative Air Humidity $(\%)$, Temperature $\left({ }^{\circ} \mathrm{C}\right)$, and Rainfall $(\mathrm{mm})$.

We considered the onset of budding when the plants showed six shoots, according to the methodology of Lajús (2004). Fruit emergence was checked daily, the beginning of maturity was determined from observations of the change of fruit color from green to purple, harvesting started when the first fruits were mature (most of the fruits showed a purplish color).

Average branch length was measured in $\mathrm{cm}$ using a ruler, average branch diameter was measured in $\mathrm{mm}$ using a digital caliper and transformed into $\mathrm{cm}$ for better graphic presentation. Number of leaves and fruits were measured by direct counting at each evaluation.

Monitoring of the development of fruit length and diameter was performed by measuring the fruits with the aid of a digital caliper ( $\mathrm{mm}$ ) every four days, starting when the fruits had a length of about $10 \mathrm{~mm}$.

Number of fruits per plant was recorded every seven days (evaluation day) from the beginning of their appearance by direct counting. Yield (kg plant ${ }^{-1}$ ) was obtained by harvesting and weighing the fruits on an analytical precision scale.

Absolute growth rate (AGR) was calculated according to the recommendations for plant growth analysis, following Oliveira, Mesquita and Freitas (2002).
To analyze phenology, we used descriptive statistics. To assess quantitative variables, we used regression analysis; qualitative variables were submitted to comparison of means by Tukey's test at $5 \%$ probability. We used the program System for Analysis of Variance, SISVAR (FERREIRA, 2011).

\section{RESULTS AND DISCUSSION}

After pruning, fig plants showed good uniformity and growth as well as normal branch development, with large broad leaves, probably due to the high temperatures recorded in September and October, with average temperature of around $28^{\circ} \mathrm{C}$ (Figure 1).

Table 1 shows that after pruning, the average time for plants to form six shoots was 12 days. Average time from budding to the development of the first fruits was 61 days, but with non-uniform fruiting and a difference between the ripening stages and the harvesting of fruits. Average time from the beginning of fruit development to maturity (color change) was 43 days; average time from the start of ripening until early harvesting stage (completely purple fruits), when the fruits are suitable for fresh consumption, was 14 days.

Table 1. Phenological behavior of the 'Roxo de Valinhos' fig cultivar.

\begin{tabular}{lcrr}
\hline $\begin{array}{l}\text { Characteristic } \\
\text { assessed }\end{array}$ & Date & Number of Days & NDAP \\
\hline Pruning & $07 / 24 / 2015$ & - & - \\
Sprouting & $08 / 05 / 2015$ & 12 & 12 \\
$1^{\text {st } \text { appearance of fruit }}$ & $10 / 05 / 2015$ & 61 & 73 \\
Early ripening & $11 / 17 / 2015$ & 43 & 116 \\
Early harvest & $12 / 01 / 2015$ & 14 & 130 \\
\hline Overall & & $\mathbf{1 3 0}$ & \\
\hline
\end{tabular}

NDAP: number of days after pruning.

- = Start of evaluation.

Rev. Caatinga, Mossoró, v. 30, n. 3, p. 802 - 810, jul. - set., 2017 
According to Caetano et al. (2012) in the manual of technical recommendations for fig tree cultivation, although the fig tree has originated from temperate climates, it does not require bud dormancy break and therefore opens its buds earlier in warmer climates, shifting each of the following phases forward.

Similarly, Lajús (2004) measured only 15 days between pruning and budding of fig trees in the region of Passo Fundo-RS, which matches the observations of our work.

The values obtained in this study are lower than those found by Norberto et al. (2001), evaluating different pruning times of the cultivar 'Roxo de Valinho' in Lavras-MG at a mean temperature of $28^{\circ} \mathrm{C}$ and relative humidity of $67 \%$. The interval between pruning and harvesting was 162 and 151 days for plants pruned on 15 and 30 July, respectively, thus showing that in hot and dry weather conditions, the productive cycle of the 'Roxo de Valinhos' fig cultivar was shorter.

Photoperiod, corresponding to the time in which plants perform photosynthesis, affects both growth and development of crops; thus, at higher latitudes with longer photoperiods during the growing season, yields are greater (SENTELHAS; MONTEIRO, 2009).

In the conditions of Botucatu-SP, Souza et al. (2009) found that between pruning and beginning of harvest, the interval was of 139 days when plants were pruned during August and at temperatures of $36^{\circ} \mathrm{C}$. These same authors report that the variations in crop cycles are caused by differences in temperature fluctuations. These results confirm the values observed here, because with increasing temperatures, fig cycles were shorter.

Monteith and Elston (1996) report that for the plants to complete their entire cycle or part of it, it is necessary to take into account the sum of degree-days (heat accumulation), since this can be used to characterize the phenological stages and/or yields.

According to Lajús (2004), the phenological stages of plants are significantly affected by temperature; with increasing temperature, it is possible that some steps are shifted forward, such as the onset of budding, vegetative growth, and harvest maturity.

The phenology of plant species in tropical regions has been relatively little studied, and there is a lack of standardized terms and methods. However, knowledge of plant phenology can be of great importance in the planning, execution, and organization of agricultural activities (FERRAZ et al., 1999; FALCÃO; CLEMENT; GOMES, 2003).

In terms of branch length (Figure 2), we observed a constant linear increase. With increasing numbers of evaluations, there was a steady increase of $0.0134 \mathrm{~cm} \mathrm{day}{ }^{-1}$, with an average of $1.22 \mathrm{~m} \mathrm{branch}^{-1}$ across 91 days.

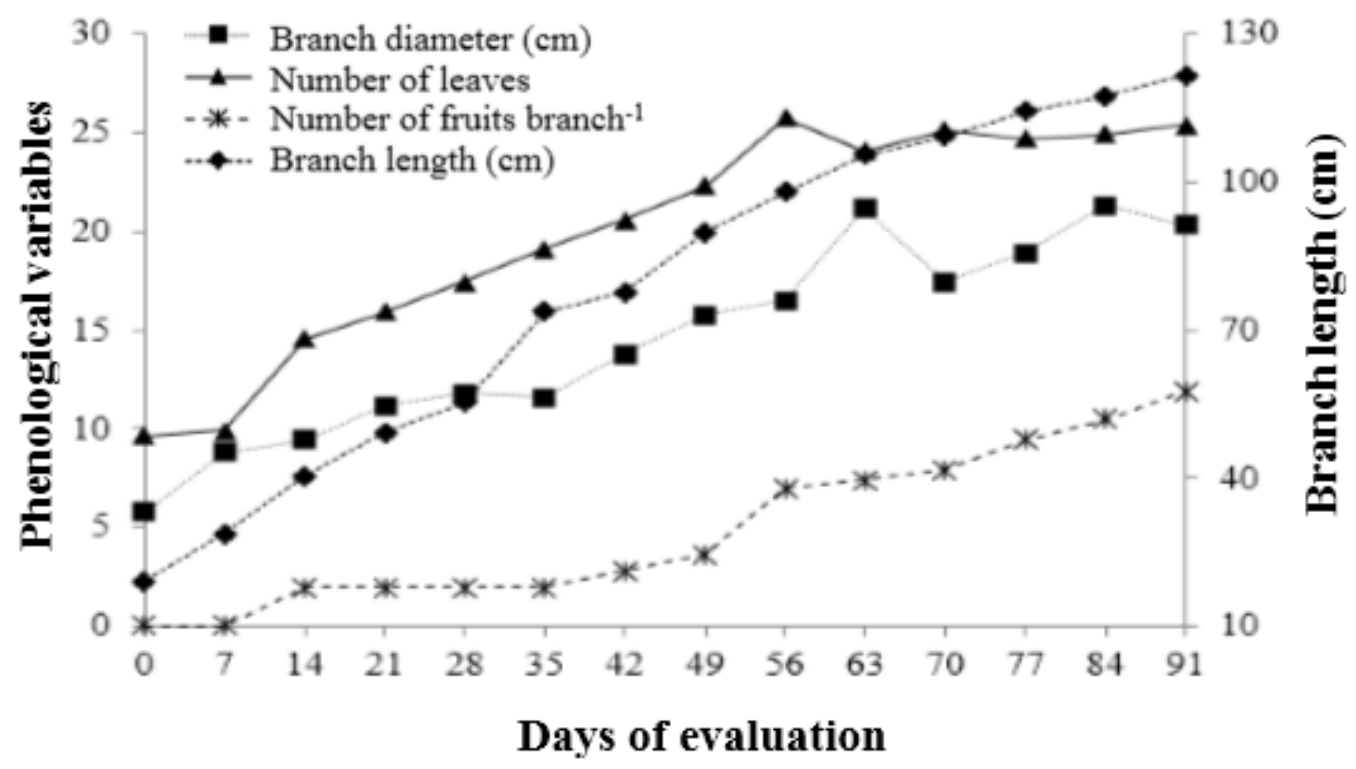

Figure 2. Phenological variables of the 'Roxo de Valinhos' fig cultivar.

The values obtained here are higher than those found by Norberto et al. (2001), corresponding to $91.33 \mathrm{~cm}$; yet, Celedonio et al. (2013), evaluating the growth of fig trees in three cultivation environments at 90 days, found a value of $110.50 \mathrm{~cm}$ at the field level. Silva et al. (2011), evaluating the growth of fig trees in different growing conditions in the region of Botucatu (SP), found values for branch length of around $1.28 \mathrm{~m}$, which are similar to those found by Dalastra et al. (2009), who measured values ranging from 1.20 to $1.30 \mathrm{~m}$.

According to Celedonio et al. (2013), the vegetative development of the crop depends on the absorption and processing of water, energy, $\mathrm{CO}_{2}$, and soil nutrients.

Figure 2 shows that branch diameter was 
highest at 63 days of evaluation $(21.13 \mathrm{~mm})$, indicating maximum growth rate, being of $21.13 \mathrm{~mm}$; taking into account the initial diameter of the branches, there was an increase of $27.35 \%$.

Leonel and Tecchio (2010) found average branch length values ranging from 49.01 to $53.99 \mathrm{~mm}$, for not irrigated and irrigated plants, respectively, in the first season. While in the second crop, the average values corresponded to 60.32 and $61.15 \mathrm{~mm}$, without and with the use of irrigation, respectively. Compared to our study, growth was much more vigorous However, our values are close to those found by Silva et al. (2011), where average branch diameter of covered and irrigated trees was $29.71 \mathrm{~mm}$.

Regarding shoots, higher vegetative growth rates, according to Souza et al. (2009), occur because of the high temperatures after pruning, thus enabling competition between the drains of photoassimilates, represented by the growth of branches and shoots and the development of fruits.

In terms of leaf number, there was a linear increase at to 56 days, with a maximum number of 25.79 leaves per branch, which remained practically stable between 63 and 91 days, with a minimum difference of 1.35 leaves (Figure 2).

Maximum leaf number per branch was higher in our study than in the work of Silva et al. (2011), who studied the growth of fig trees under different growing conditions and reported minimum and maximum values of 13.32 and 15.87, respectively. Yet, the values reported by Celedonio et al. (2013) for the region of Limoeiro do Norte-CE, evaluating fig plants in three cultivation environments, show that plants at the field level showed 44 leaves at 90 days of evaluation.

Climatic factors such as temperature, humidity, and radiation can influence the phenological, vegetative, and productive stages of the crops; they usually vary depending on the region.

Bergamaschi (2007) reports that higher temperatures accelerate plant development, while low temperatures prolong the cycle; outside these limits, plants slow down their metabolism and suffer stress by cold or heat. As for the photoperiod, flowering induction is the main response mechanism because it determines the transition from vegetative growth to reproduction, which is essential for the production of fruits and seeds. This cycle is changed when plants are cultivated in different seasons or latitudes.

In regions alternating dry and wet periods, plant phenology is subject to water availability; this is the case in semi-arid regions and savannahs. In Brazil, especially in the northeastern semi-arid region and in the Cerrado, the conditions and the phenological patterns of plants tend to follow the seasonal fluctuation of rainfall, as mild and short-term stresses tend to shift flowering and the onset of fruiting, thereby altering the cycle of plants (BERGAMASCHI, 2007).

In terms of number of fruits per branch (Figure 2), this variable increased throughout the evaluation period; the two first fruits appeared at 73 days after pruning, and at the end of the evaluation periods, average fruit number per branch was 11.90. Fruit appearance rate was constant up to the initial 42 days.

Average fruit number per branch found in this study was similar to the findings of Norberto et al. (2001), who counted 11.83 fruits per branch in cultivations without the application of hydrogen cyanamide or irrigation.

We noted a classical, sigmoid plant growth curve (Figure 3) with increased fruit size over time; fruit growth was initially slow, with a constant increase until maximum rate (length and diameter of 26.5 and $27.2 \mathrm{~mm}$, respectively) was achieved on day 16. Fruit growth (length and diameter) was first evaluated when fruits had a length of $10 \mathrm{~mm}$ and continued until the day of harvest.

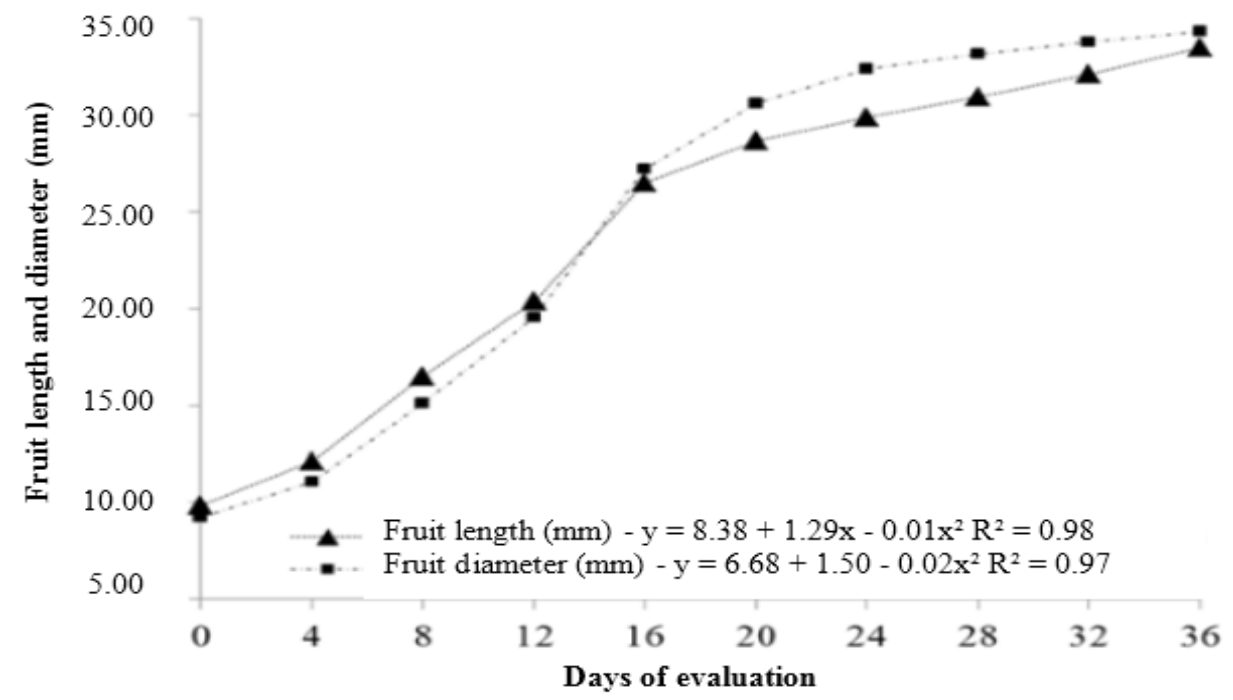

Figure 3. Fruit growth curve of the 'Roxo de Valinhos' fig cultivar. 
After 36 days, average fruit length was $33.5 \mathrm{~mm}$ and average diameter was $34.3 \mathrm{~cm}$. The most significant increase was observed on day 16 , where diameter exceeded length.

Rodrigues, Correa and Boliani (2009), analyzing the behavior of mutant selections of the fig tree cv. 'Roxo de Valinhos', found results of 5.3 and $4.17 \mathrm{~cm}$ for fruit length and diameter, respectively, which were higher than those in the present study.

Our values are lower than those found by
Freitas et al. (2015), who measured $52.9 \mathrm{~mm}$ and $45.8 \mathrm{~mm}$, respectively, for fruit length and diameter, in open-field cultivation in the region of Limoeiro do Norte-CE.

The highest fruit growth rate (Figure 4) in terms of length $\left(1.52 \mathrm{~mm} \mathrm{day}{ }^{-1}\right)$ was observed between 12 and 16 days, while the highest rate in terms of diameter $\left(1.55 \mathrm{~mm} \mathrm{day}{ }^{-1}\right)$ was found between day 16 and 20 . After this, there fruit growth rate decreased until harvest.

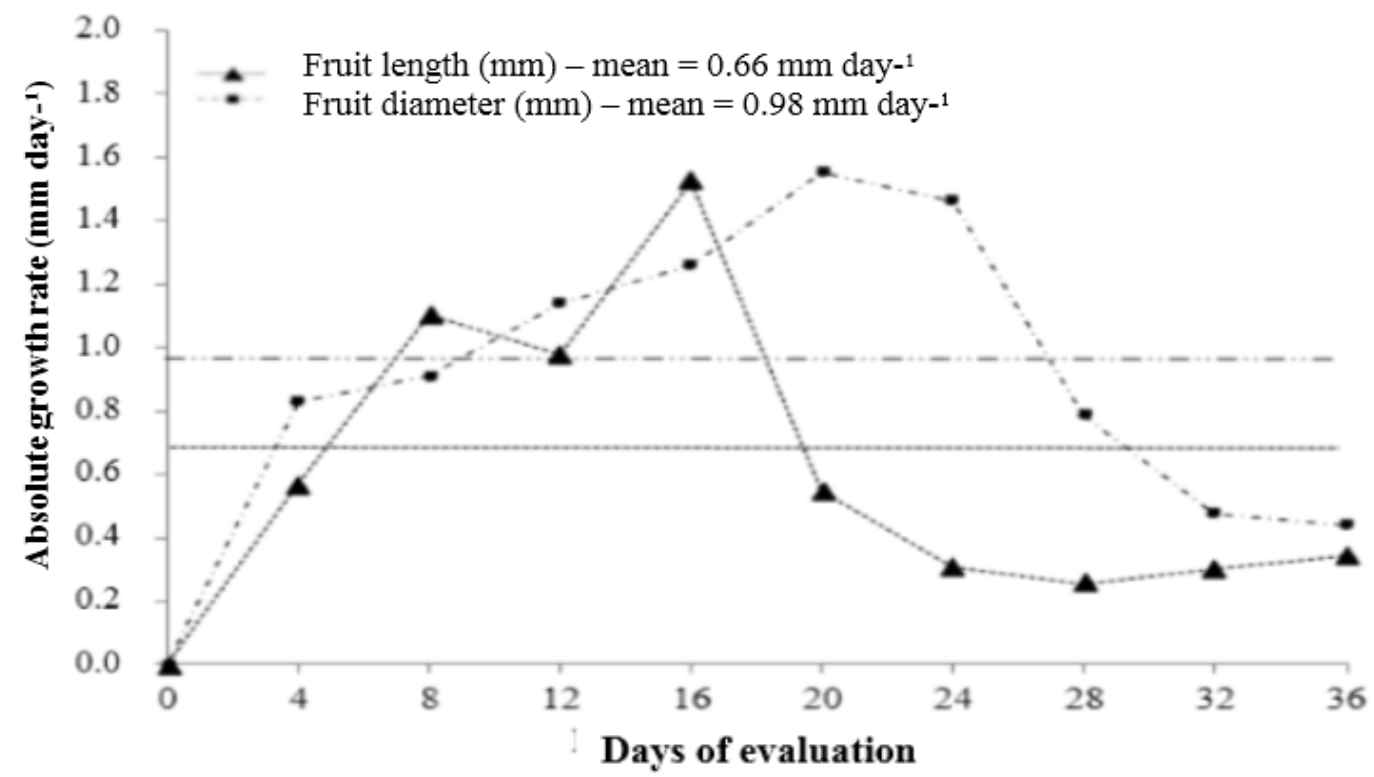

Figure 4. Absolute growth rate of fig fruits of the 'Roxo de Valinhos' cultivar.

Our data are similar to those found by Rodrigues et al. (2012), who observed length values from 2.5 to $7.0 \mathrm{~cm}$ and diameter values between 2.5 and $5.5 \mathrm{~cm}$. According to these authors, this variation may be due to the mutation of plants. The data are correlated with those of Campagnolo et al. (2009) for the variables length and diameter, whose values ranged from 3.70 to $5.30 \mathrm{~cm}$ and from 2.66 to $3.79 \mathrm{~cm}$, respectively.

Evaluating of absolute growth rates can be a tool to efficiently plan and undertake weed control, fertilization, and irrigation, among others, in addition to determining the correct harvest time.

In terms of fruit yield (Figure 5), highest number of fruits per plant was 159.60, which resulted in a yield of $4.15 \mathrm{~kg}$ plant $^{-1}$.

These values are close to those reported by Trevisan (2014) when evaluating different irrigation depths; maximum value was 166.25 fruits per plant, only $4 \%$ higher than in our study.

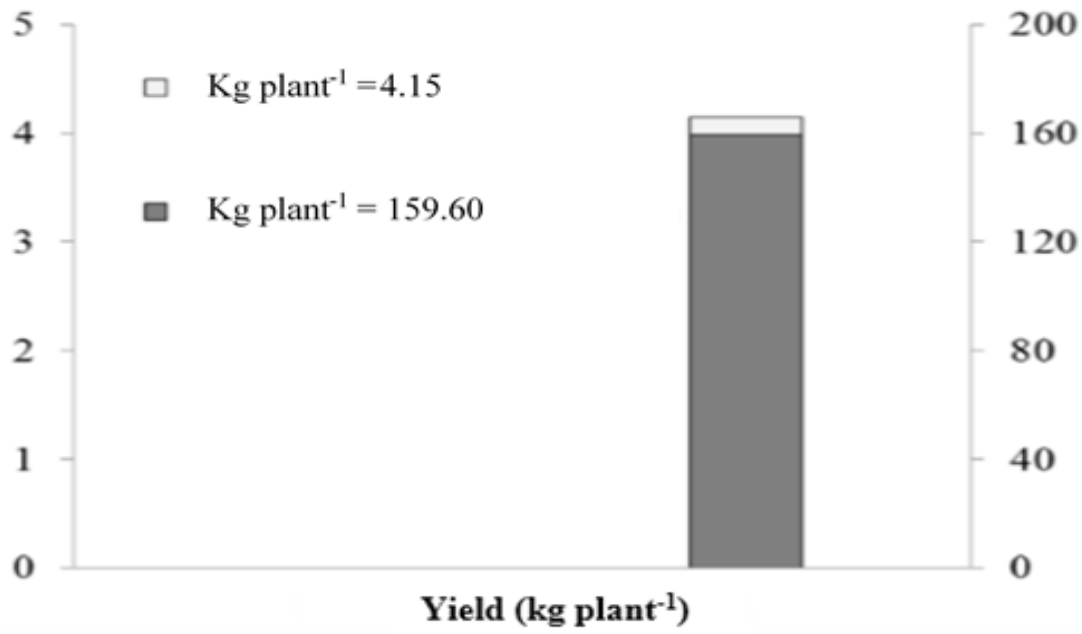

Figure 5. Yield (kg plant $\left.{ }^{-1}\right)$ per plant of the 'Roxo de Valinhos' fig cultivar. 
Campagnolo et al. (2009), when submitting fig plants of the cv. 'Roxo de Valinhos' to a lopping system, found the largest number of fruits per plant (156.80) in plants with six branches; this finding is similar to the results of our study.

In terms of fruit yield, studies by Campagnolo et al. (2009) under organic growing conditions and using four-year-old plants, obtained values of 1.34 and $1.73 \mathrm{~kg}$ per plant, for plants without lopping and with 6 and 12 branches, respectively; these values are below the values of this study, which was conducted under conventional cultivation conditions.

According to Figure 6, maturity stage III showed the highest fruit weight (38.93 g), appearing to be superior than the other maturity stages as these occurred at more advanced stages of development, i.e., closer to harvest; however, maturity stage I, at harvest, had the lowest value, corresponding to $14.80 \mathrm{~g}$, as fruit growth was still at the beginning.

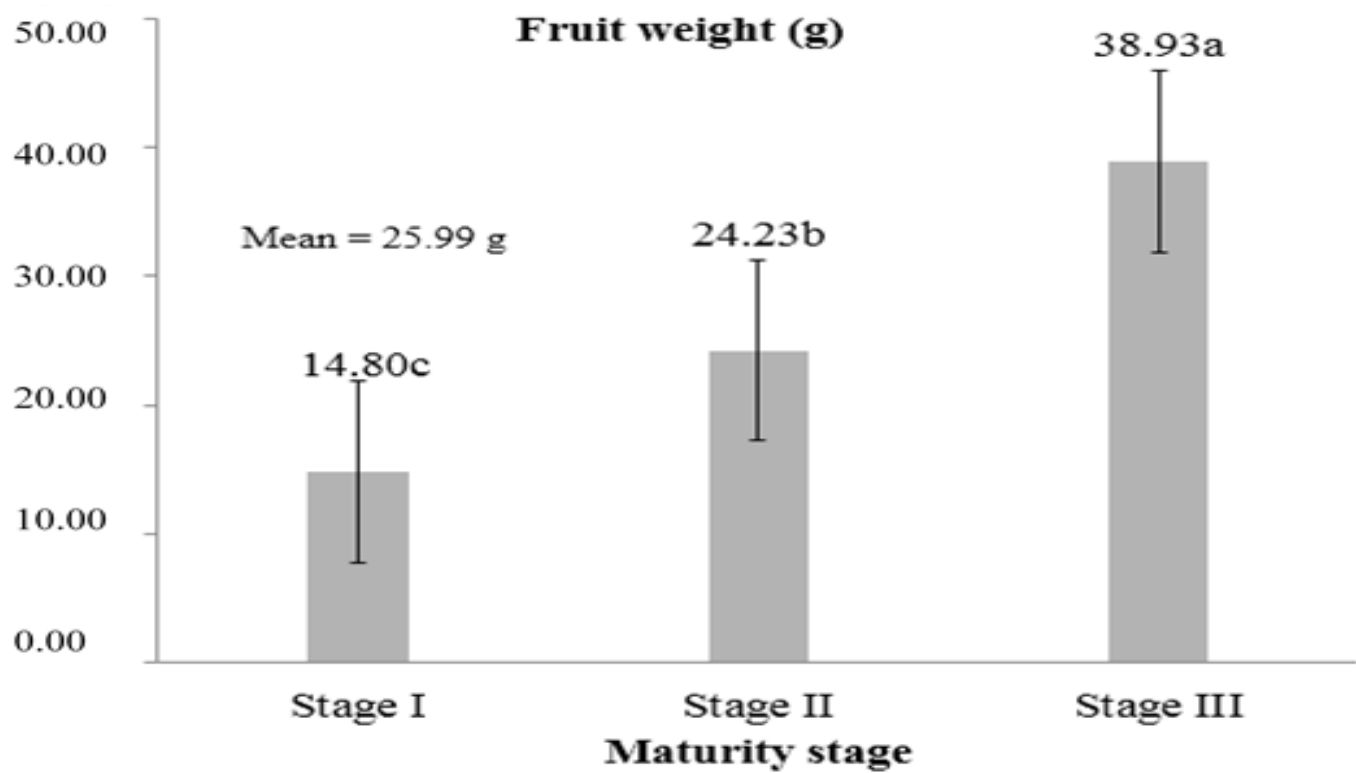

Figure 6. Fruit weight $(\mathrm{g})$ of the 'Roxo de Valinhos' fig cultivar, at three maturity stages. Different letters indicate statistically significant differences.

Mazaro et al. (2005) studying the physicochemical characteristics of fig fruits, cv. 'Roxa de Valinhos', verified a weight of $27.79 \mathrm{~g}$.

Freitas et al. (2015), analyzing the physicochemical characteristics of figs under different conditions in Chapada do Apodi-CE, found an average weight of $41.41 \mathrm{~g}$ under cultivation in the open air, yet Gonçalves et al. (2006) found values of $53.23 \mathrm{~g}$ for mature fruits, both higher than the values found in this study.

\section{CONCLUSION}

Fig trees are highly adapted to the cultivation in semi-arid regions and show precocity when compared to fig trees cultivated in temperate regions, in all phenological stages. The studied cultivar 'Roxo de Valinhos' showed promising results in terms of cultivation in Mossoró-RN, Brazil.

\section{REFERENCES}

ARAÚJO, R. R.; SANTOS, E. D. ; LEMOS, E. D. P. Fenologia do muricizeiro byrsonima verbascifolia (L.) rich em zona de tabuleiro costeiro do nordeste brasileiro. Ciência Agrícola, Rio Largo, v. 12, n. 1, p. 1-8, 2014.

BERGAMASCHI, H. O clima como fator determinante da fenologia das plantas. In: REGO, C. M.; NEGRELLE, R. R. B.; MORELATTO, L. P. C. (Eds.). Fenologia: ferramenta para conservação, melhoramento e manejo de recursos vegetais arbóreos. Colombo: Embrapa Florestas, 2007. v. 1, cap. 16, p. 291-310.

CAETANO, L. C. S. et al. Recomendações técnicas para a cultura da figueira. Vitória, ES: INCAPER; 2012. Disponível em: <http:// biblioteca.incaper.es.gov.br/digital/bitstream/ item/37/1/Recomendacoes-tecnicas-sobre-culturafigueira.pdf $>$. Acesso em: 20 jan. 2016.

CAMILO, Y. M. V. et al. Fenologia, produção e precocidade de plantas de Eugenia dysenterica visando melhoramento genético. Revista de Ciências Agrárias, Belém, v. 36, n. 2, p. 192-198, 2013

CAMPAGNOLO, M. A. et al. Sistema desponde na produção de figos verdes 'Roxo de Valinhos'. Ciência Rural, Santa Maria, v. 40, n. 1, p. 25-29, 
2009.

CARMO FILHO, F.; OLIVEIRA, O. F. Mossoró: um município do semiárido nordestino, caracterização climática e aspecto florístico. Mossoró: ESAM, 1995. 62 p. (Coleção Mossoroense, série B).

CELEDONIO, C. A. et al. Crescimento da figueira em três ambientes de cultivo, sob aplicação de biofertilizante bovino via fertirrigação. Revista Brasileira de Agricultura Irrigada, Fortaleza, v. 7, n. 6, p. $358-370,2013$.

CHAGAS, E. A. et al. Phenological assessment of cultivars and selections of peach and nectarine trees with low exigency of chilling. Acta Horticulturae, Lleida, v. 1, n. 962, p. 39-44, 2012.

DALASTRA, I. M. et al. Épocas de poda na produção de figos verdes' Roxo de Valinhos' em sistema orgânico na região oeste do Paraná. Revista Brasileira de Fruticultura, Jaboticabal, v. 31, n. 2, p. 447-453, 2009.

FALCÃO, M. A.; CLEMENT, C. R.; GOMES, J. B. M. Fenologia e produtividade da sorva (Couma utilis (Mart.) Muell. Arg.) na Amazônia Central. Acta Botânica Brasileira, São Paulo, v. 17, n. 4, p. 541-547, 2003.

FERRAZ, D. K. et al. Fenologia de árvores em fragmento de mata em São Paulo, SP. Revista Brasileira de Biologia, São Paulo, v. 59, n. 2, p. 305-317, 1999.

FERREIRA, D. F. Sisvar: A computer statistical analysis system. Ciência e Agrotecnologia, Lavras, v. 35, n. 6, p. 1039-1042, 2011.

FREITAS, R. N. S. et al. Caracterização pós-colheita de figos (Ficus carica L.) produzidos sob diferentes condições de cultivo na Chapada do Apodi-CE. Revista Verde de Agroecologia e Desenvolvimento Sustentável, Pombal, v. 10, n. 1, p. 43-46, 2015.

FRONZA, D. et al. Produtividade e qualidade de figos Roxo de Valinhos submetidos à fertirrigação e ao armazenamento refrigerado. Revista Ceres, Viçosa, v. 57, n. 4, p. 494-499, 2010.

GONÇALVES, C. A. A. et al. Caracterização física, físico-química, enzimática e de parede celular em diferentes estádios de desenvolvimento da fruta de figueira. Ciência e Tecnologia de Alimentos, Campinas, v. 26, n. 1, p. 220-229, 2006.

INSTITUTO BRASILEIRO DE GEOGRAFIA E ESTATÍSTICA - IBGE. Produção Agrícola Municipal. Disponível em: $<$ http:// biblioteca.ibge.gov.br/visualizacao/periodicos/66/ pam_2014_v41_br.pdf>. Acesso em: 07 mar. 2016.

LAJÚS, C. R. Desenvolvimento e produção da figueira cv. Roxo de Valinhos em ambiente protegido, submetida a diferentes épocas de poda e condução. 2004. 146 f. Dissertação (Mestre em Agronomia: Área de Concentração em Produção Vegetal) - Faculdade de Agronomia e Medicina Veterinária da Universidade de Passo Fundo, Passo Fundo, 2004.

LEONEL, S.; TECCHIO, M. A. Épocas de poda e uso da irrigação em figueira 'Roxo de Valinhos' na região de Botucatu, SP. Bragantia, Campinas, v. 69, n. 3, p. 571-580, 2010.

MAZARO, S. M. et al. Ensacamento de figos cv. Roxo de Valinhos. Scientia agrária, Dois Vizinhos, v. 6, n. 1, p. 59-63, 2005.

MONTEITH, J. L.; ELSTON, J. Climatic constraints on crop production. In: FOWDEN, L.; MANSFIELD, T.; STODDART, J. (Eds.). Plant adaptation to environmental stress. London: Chapman \& Hall, 1996. p. 3-18.

NORBERTO, P. M. et al. Efeito de época de poda, cianamida hidrogenada e irrigação na produção antecipada de figos verdes. Pesquisa Agropecuária Brasileira, Brasília, v. 36, n. 11, p. 1363-1369, 2001.

OLIVEIRA, L. E. M.; MESQUITA, A. C.; FREITAS, E. B. Análise de crescimento de plantas. Lavras, MG: Universidade Federal de Lavras. Departamento de Biologia. Setor de Fisiologia Vegetal, 2002. p. 1-9.

RODRIGUES, M. G. F. et al. Seleção de clones de figueira cv. Roxo-de-Valinhos formados por gemas irradiadas. Revista Brasileira de Fruticultura, Jaboticabal, v. 34, n. 2, p. 604-611, 2012.

RODRIGUES, M. G. F.; CORREA, L. D. S.; BOLIANI, A. C. Avaliação de seleções mutantes de figueira cv. Roxo-de-Valinhos. Revista Brasileira de Fruticultura, Jaboticabal, v. 31, n. 3, p. 771-777, 2009

SENTElHAS, P. C.; MONTEIRO, J. E. B. A. Parte I - Introdução. In: MONTEIRO, J. E. B. A. (Ed.). Agrometeorologia dos cultivos: o fator meteorológico na produção agrícola, Brasília: INMET, 2009. Cap. 1, p. 3-12.

SERRANO, L. A. L. et al. Fenologia da goiabeira 'Paluma' sob diferentes sistemas de cultivos, épocas e intensidades de poda de frutificação. Bragantia, Campinas, v. 67, n. 3, p. 701-712, 2008. 
SILVA, A. C. et al. Crescimento de figueira sob diferentes condições de cultivo. Pesquisa Agropecuária Tropical, Goiânia, v. 41, n. 4, p. 539-551, 2011.

SILVA, A. G. da. et al. Fenologia de anadenantehra macrocarpa (benth.) brenan em uma floresta estacional semidecidual no sul do Espírito Santo. Enciclopédia Biosfera, Goiânia, v. 8, n. 15, p. 938-945, 2012.

SOUZA, A. P. et al. Temperaturas basais e soma térmica para a figueira podada em diferentes épocas. Revista Brasileira de Fruticultura, Jaboticabal, v. 31, n. 2, p. 314-322, 2009.

SOUZA, M. E. et al. Atributos físico-químicos e aceitabilidade dos frutos de figueiras cultivadas na Espanha. Nativa, Sinop, v. 2, n. 3, p. 138-142, 2014.

TREVISAN, P. V. Cultura da figueira (Ficus carica L.) submetida a diferentes lâminas de irrigação por gotejamento. 2014. 78 f. Dissertação (Mestrado em Engenharia Agrícola: Área de Concentração em Engenharia de Água e Solo) - Universidade Federal de Santa Maria, Santa Maria, 2014. 